\title{
Astrobiology and habitability studies in preparation for future Mars missions: trends from investigating minerals, organics and biota
}

\author{
P. Ehrenfreund ${ }^{1,2}$, W.F.M. Röling ${ }^{3}$, C.S. Thiel ${ }^{4}$, R. Quinn ${ }^{5}$, M.A. Sephton ${ }^{6}$, C. Stoker ${ }^{5}$, \\ J.M. Kotler ', S.O.L. Direito ${ }^{3}$, Z. Martins ${ }^{6}$, G.E. Orzechowska ${ }^{7}$, R.D. Kidd ${ }^{7}$, \\ C.A van Sluis $^{8}$ and B.H. Foing ${ }^{9}$ \\ ${ }^{1}$ Leiden Institute of Chemistry, PO Box 9502, 2300 Leiden, The Netherlands \\ e-mail:p.ehrenfreund@chem.leidenuniv.nl \\ ${ }^{2}$ Space Policy Institute, Elliott School of International Affairs, Washington, DC, USA \\ ${ }^{3}$ Faculty of Earth and Life Sciences, VU University Amsterdam, Amsterdam, The Netherlands \\ ${ }^{4}$ Institute of Medical Physics and Biophysics, CeNTech, University of Münster, 48149, Münster, Germany \\ ${ }^{5}$ NASA Ames Research Center, Moffett Field, CA 94035, USA \\ ${ }^{6}$ Department of Earth Science and Engineering, Imperial College London, London SW7 2AZ, UK \\ ${ }^{7}$ Jet Propulsion Laboratory, California Institute of Technology, Pasadena, CA 91109, USA \\ ${ }^{8}$ Department of Biotechnology, Delft University of Technology, 2628 BC Delft, The Netherlands \\ ${ }^{9}$ ESA ESTEC, Postbus 299, 2200 AG Noordwijk, The Netherlands
}

\begin{abstract}
Several robotic exploration missions will travel to Mars during this decade to investigate habitability and the possible presence of life. Field research at Mars analogue sites such as desert environments can provide important constraints for instrument calibration, landing site strategies and expected life detection targets. We have characterized the mineralogy, organic chemistry and microbiology of ten selected sample sites from the Utah desert in close vicinity to the Mars Desert Research Station (MDRS) during the EuroGeoMars 2009 campaign (organized by International Lunar Exploration Working Group (ILEWG), NASA Ames and ESA ESTEC). Compared with extremely arid deserts (such as the Atacama), organic and biological materials can be identified in a larger number of samples and subsequently be used to perform correlation studies. Among the important findings of this field research campaign are the diversity in the mineralogical composition of soil samples even when collected in close proximity, the low abundances of detectable polycyclic aromatic hydrocarbons (PAHs) and amino acids and the presence of biota of all three domains of life with significant heterogeneity. An extraordinary variety of putative extremophiles, mainly Bacteria and also Archaea and Eukarya was observed. The dominant factor in measurable bacterial abundance seems to be soil porosity and lower small (clay-sized) particle content. However, correlations between many measured parameters are difficult to establish. Field research conducted during the EuroGeoMars 2009 campaign shows that the geological history and depositional environment of the region, as well as the mineralogy influence the ability to detect compounds such as amino acids and DNA. Clays are known to strongly absorb and bind organic molecules often preventing extraction by even sophisticated laboratory methods. Our results indicate the need for further development and optimization of extraction procedures that release biological compounds from host matrices to enable the effective detection of biomarkers during future sampling campaigns on Earth and Mars.
\end{abstract}

Received 25 January 2011, accepted 1 April 2011, first published online 12 May 2011

Key words: astrobiology, habitability, life detection, field analogue research, Mars, organics, clays, landing site criteria.

\section{Introduction}

The objective of future international planetary exploration programmes is to implement a long-term plan for the robotic and later human exploration of the Moon, Mars and NearEarth Asteroids (NEOs). Mars is the central object of interest for habitability studies and life detection beyond the Earth and can be visited frequently by robotic spacecrafts, paving the way for returned samples and human exploration. NASA's Mars Science Laboratory (MSL) to be launched in November
2011 will explore the Martian surface, followed by the Mars Atmosphere and Volatile EvolutioN (MAVEN) spacecraft, scheduled for launch in late 2013. A long-term ESANASA cooperation plan for the exploration of Mars with missions in 2016 and 2018 has been recently developed that will investigate the atmosphere and the surface of Mars for signs of habitability and life and prepare for the Mars Sample Return (MSR) mission (Grant et al. 2010). China will contribute the Yinghou-1 (YH-1) orbiter to the Russian Phobos-Grunt sample return mission in 2011 and conduct 
space-environment, atmospheric, gravity and surface-imaging studies of Mars.

Our knowledge about planet Mars has benefited over the last few decades from a fleet of orbital and landed spacecraft such as Mars Global Surveyor, Mars Odyssey, the Mars Exploration Rovers, Mars Express and the Mars Reconnaissance Orbiter. Results from these missions indicate that Mars had a different climate in the past. On ancient Mars water was persistent in shallow surface bodies, lakes, connected networks and as groundwater near the surface (Malin et al. 2003; Knoll \& Grotzinger 2006; Murchie et al. 2009; Squyres et al. 2009). A diverse suite of minerals, including hydrated sulphates, phyllosilicates and silica, produced during aqueous alteration of Martian crustal rocks has been identified both from orbit and from the Martian surface (e.g. Chevrier \& Mathé 2007; Arvidson et al. 2008; Hecht et al. 2009; Poulet et al. 2009). Recent observations with instruments onboard Mars Express and the Mars Reconnaissance orbiters identified more than 990 hydrated mineral exposures on Mars (Carter et al. 2011). At the Mawrth Vallis region, phyllosilicate units are observed that resemble terrestrial sedimentary deposits (Bishop et al. 2011). Recent Earth-based observations have detected methane in the atmosphere of Mars (e.g. Formisano et al. 2004; Mumma et al. 2009). Zahnle et al. (2011) critically review these results and argue that variable methane on Mars is physically and chemically implausible. Results from the Phoenix mission have yielded new insights into the composition of the Martian soil. A slightly alkaline soil $\mathrm{pH}$ and perchlorate as dominant soluble anion were determined by the Phoenix Wet Chemical Laboratory (Hecht et al. 2009). $\mathrm{CO}_{2}$ release measured in the Thermal Evolved Gas Analyzer indicates the presence of calcium carbonate (Boynton et al. 2009).

Robotic and human operations in space can be effectively prepared on Earth, as terrestrial extreme environments often provide analogues to landing and operation sites on the Moon and Mars. Existing Earth-based field research programmes preparing for planetary exploration are diverse (Ansdell et al. 2011). Many space instruments augment their flight readiness level through tests in planetary analogue regions on Earth.

Lessons learned from sample collection, handling and in-situ analysis at these sites help to overcome contamination issues as well as improve instrument performance. Using Mars regolith analogues to test physical and chemical properties such as $\mathrm{pH}$, redox potential, elemental composition, conductivity and organic content are part of the interdisciplinary preparation phase to search for organic molecules and life on Mars (Peeters et al. 2009; Marlow et al. 2010). The Atacama Desert is being used as a Mars analogue field test site for the development of a number of new technologies and instruments for future Mars exploration (Navarro-Gonzáles et al. 2003). The extremely arid Atacama Desert contains very low concentrations of biota and organic matter in the soil (see Marlow et al. 2010. for a review). Amino acid data from the Yungay region are often below the ppb detection limit (Peeters et al. 2009). Lester et al. (2007) found a biomass between $8.5 \times 10^{6}$ and $6.0 \times 10^{7}$ cells/g based on phospholipid fatty acid (PLFA) measurements, and between $6.3 \times 10^{2}$ and $5.2 \times 10^{2}$ colony-forming units (CFU)/g of culturable biomass in Yungay soils. The total organic content (TOC) was estimated between 560 and $765 \mathrm{ppm}$. Connon et al. (2007) studied the bacterial diversity in the Atacama Desert and detected Actinobacteria, Protobacteria, Firmicutes and TM7.

In this paper, we report on astrobiology field research from the Mars Desert Research Station (MDRS) in Hanksville, Utah conducted during the EuroGeoMars 2009 campaign (Foing et al. 2011). MDRS is located in a geological formation that was formed 150 million years ago (Hintze \& Kowallis 2009; Clarke \& Stoker 2011). Geology close to the habitat includes the Middle Jurassic Summerville Formation, the Late Jurassic Morrison Formation, the Early Cretaceous Dakota Sandstone and the middle Cretaceous Mancos Shale Formations (Clarke \& Stoker 2011; Stoker et al. 2011). Sedimentary deposits of sands, evaporites and clays are found; gypsum and a variety of clay minerals have been detected (Borst et al. 2010). In addition, MDRS is located in an area characterized by red-coloured hills, soils and sandstones due to the presence of iron oxides (e.g. haematite) (Chan et al. 2004; Ormö et al. 2004). We have investigated ten selected samples from different geological formations (Mancos Shale, Morrison and Dakota) and also chose a variety of locations (surface, subsurface and cliffs) for mineralogy, organic content and biota (Direito et al. 2011; Kotler et al. 2011; Martins et al. 2011; Orzechowska et al. 2011; Thiel et al. 2011a). In this paper, we analyse the individual studies in an attempt to establish correlations among environmental parameters and biota. The results are interpreted in the context of future missions that target the identification of organic molecules and biomarkers on Mars.

\section{Sample analysis}

Data from several studies on ten selected samples are compiled and compared in this paper, see Fig. 1. Soil samples were collected under sterile conditions at desert areas of Utah in the vicinity of MDRS. The samples were partly analysed in situ and later distributed to the various laboratories for subsequent analysis of mineralogy, organic content and microbiology.

Soil sample properties that were measured in the MDRS habitat laboratory included $\mathrm{pH}$ and elemental composition of nitrate, potassium $(\mathrm{K})$, phosphorous $(\mathrm{P})$ and magnesium $(\mathrm{Mg})$ (Table 1). For the $\mathrm{pH}$ measurements, the soil was dissolved in distilled, sterile water.

The soil flocculation reagent, contained in the test kit, was added and solid particles were allowed to settle down before analysis of the $\mathrm{pH}$, first with a wide range dye indicator followed by a narrow range indicator. The direct on-site soil analysis was performed with a field soil test kit (La Motte, Eijkelkamp, The Netherlands). For measurements of soil concentrations of nitrate, $\mathrm{P}, \mathrm{K}$ and $\mathrm{Mg}$, the soil was dissolved in an extracting solution provided with the kit. This extracting solution contained sodium acetate and was adjusted to $\mathrm{pH} 4.8$ to extract the soluble nutrients such as phosphorous and nitrogen, as well as soluble exchangeable cations (e.g., potassium and magnesium). The nitrate analysis was based 
Table 1. On-site (in situ) soil kit analysis after sample collection, see also 'Sample analysis' and 'Results and discussion' sections

\begin{tabular}{|c|c|c|c|c|c|c|c|c|}
\hline Sample & Coordinates & Depth & Formation & $\mathrm{pH}$ & Nitrate/N (ppm) & $\mathrm{K}(\mathrm{ppm})$ & $\mathrm{P}(\mathrm{ppm})$ & $\mathrm{Mg}(\mathrm{ppm})$ \\
\hline P1 & $\mathrm{N} 38.43621^{\circ} \mathrm{W} 110.81946^{\circ}$ & Gully & Mancos/Tunuck & 7.6 & 7 & 250 & 5 & $<5$ \\
\hline $\mathrm{P} 2$ & $\mathrm{~N} 38.40746^{\circ} \mathrm{W} 110.79280^{\circ}$ & Cliff & Morrison & 8.1 & $>75$ & 175 & 12 & - \\
\hline P3 & $\mathrm{N} 38.40737^{\circ} \mathrm{W} 110.79261^{\circ}$ & Surface & Morrison & 8.0 & $<5$ & 205 & 12 & $<5$ \\
\hline P5 & $\mathrm{N} 38.42638^{\circ} \mathrm{W} 110.78342^{\circ}$ & Cliff & Morrison & 9.0 & $>75$ & 200 & 100 & - \\
\hline P6 & $\mathrm{N} 38.42638^{\circ} \mathrm{W} 110.78342^{\circ}$ & Cliff & Morrison & 7.6 & 75 & 190 & 85 & - \\
\hline P7 & $\mathrm{N} 38.45424^{\circ} \mathrm{W} 110.79092^{\circ}$ & Riverbed & Morrison & 9.6 & 10 & 180 & 10 & - \\
\hline P8 & $\mathrm{N} 38.43755^{\circ} \mathrm{W} 110.88725^{\circ}$ & Surface & Mancos Shale & 8.5 & 65 & 250 & 5 & - \\
\hline P10 & $\mathrm{N} 38.43896^{\circ} \mathrm{W} 110.89001^{\circ}$ & Surface & Mancos Shale & 8.5 & 7 & 190 & 5 & - \\
\hline P13 & $\mathrm{N} 38.40630^{\circ} \mathrm{W} 110.79547^{\circ}$ & Shell surface & Dakota & 8.7 & 7 & 140 & 100 & - \\
\hline P14 & $\mathrm{N} 38.40630^{\circ} \mathrm{W} 110.79547^{\circ}$ & $15 \mathrm{~cm}$ & Dakota & 7.0 & 30 & 225 & 80 & - \\
\hline
\end{tabular}

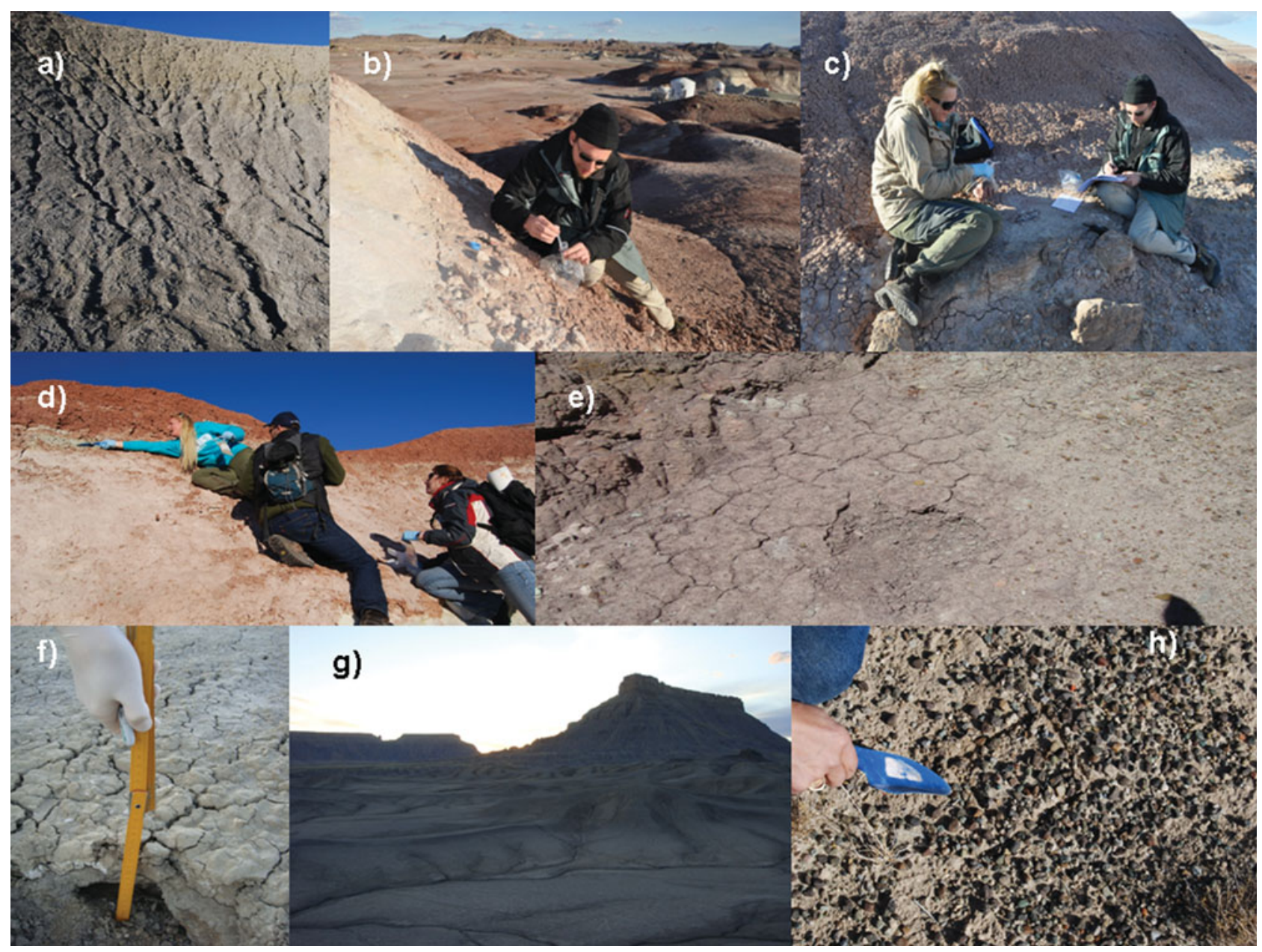

Fig. 1. Sampling sites for P-1 to P-14. The ten samples were selected to represent different geological regions and partly due to similarities to Martian features. (a) Sample site P-1 belongs to the Mancos/Tunuck Formation and shows structures that resemble gullies on Mars. (b) P-2 represents a white sand layer site from the Morrison Formation close to the MDRS habitat. (c) The P-3 sampling site is within several metres of P-2 from the Morrison Formation and close to the MDRS habitat. (d) P-5 and P-6 are two layers sampled within a few $\mathrm{cm}$ from a cliff in the Morrison Formation. Whereas P-5 is a brown-reddish clay-rich material, P-6 was sampled from a $10 \mathrm{~cm}$ green layer (turf) just above. (e) P-7 was sampled from a riverbed in Morrison Formation. (f) P-8 sampling site belongs to the Mancos Shale Formation and soils are ash-like grey material with $\sim 4 \%$ organic material. (g) P-10 sampling site belongs to the Mancos Shale Formation with ash-like soils and contains sulphates, clays and carbonates. (h) Sampling site P-13 belongs to the Dakota Formation that is covered with shells. Samples P-14 was taken $15 \mathrm{~cm}$ below the shell surface and shows very different characteristics (see text).

on a procedure where two dye intermediates were coupled in the di-azo reaction to form a colour dyestuff (Denige's test). The potassium concentration was determined by measuring the precipitate formed by potassium salts and sodium cobalt nitrite in denatured ethyl alcohol. In the phosphorous test, salts of complex ammonium phosphomolybdate were measured 


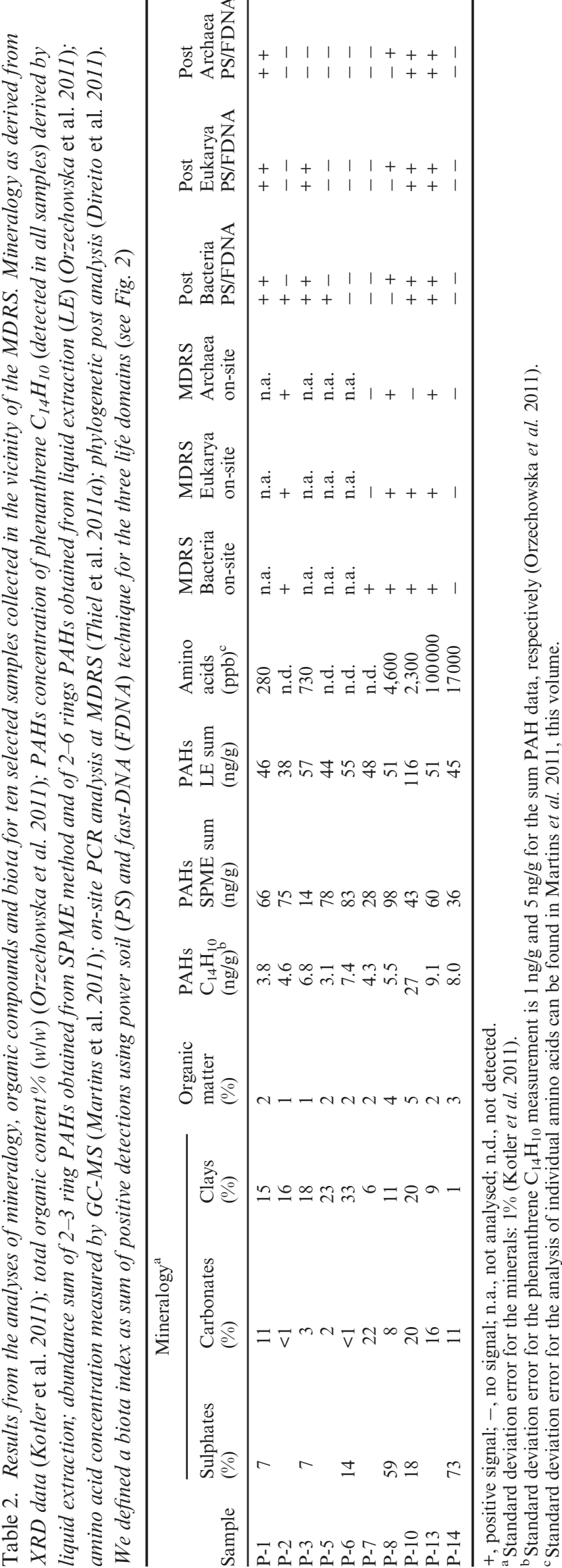

after phosphates reacted with ammonium molybdate. Addition of the reducing agent containing stannous chloride resulted in production of the blue molybdenum oxide colour. The magnesium test analysed the amount of precipitate that was formed between magnesium and sodium hydroxide using the dye titan yellow that was absorbed on the precipitate. The degree of colour depends on the amount of formed precipitate.

On-site polymerase chain reaction (PCR) using primers specific for ribosomal DNA in combination with agarose gels identified biota of several domains (Bacteria, Archaea and Eukarya) shortly after sample collection (Thiel et al. 2011a). Quantification of soil DNA concentration could be achieved by purifying DNA from soil samples using the PowerSoil DNA Isolation Kit (MOBIO Laboratories, USA) and the concentration was measured using the Qubit dsDNA HS assay kit together with the Qubit Fluorometer (Invitrogen, Germany). The analysis is based on the increase of fluorescence of the dye Pico Green after binding to double stranded (ds) DNA. The measurement was accomplished according to the manufacturer's manual (http://probes.invitrogen.com/media/ pis/mp32851.pdf). Briefly, a $10 \mu \mathrm{l}$ aliquot of the DNA sample was added to $190 \mu \mathrm{l}$ of the Qubit working solution which is a 1:200 dilution of dsDNA HS reagent in Qubit dsDNA HS buffer. After storing the reaction at room temperature for 2 minutes, the fluorescence was measured with the Qubit Fluorometer and the DNA concentration was calculated considering the measured standard values used for calibration of the instrument.

Post-analysis studies determined the total organic content (TOC) (Orzechowska et al. 2011). The concentrations of polycyclic aromatic hydrocarbons (PAHs) have been determined by using the solid phase micro-extraction (SPME) method that provides good recoveries for small PAHs that are usually targeted with payload instruments of planetary missions (Orzechowska et al. 2011). Amino acids were extracted from soil samples and analysed on a Gas Chromatograph Mass Spectrometer (GC-MS) (Martins et al. 2011). Culture-independent molecular analyses directed at ribosomal RNA, was used to investigate the detailed microbiology of desert samples (Direito et al. 2011). Mineralogy investigations were performed using infrared spectroscopy and X-ray diffraction analysis (Kotler et al. 2011).

In order to relate the biological and physicochemical data, statistical analysis was performed using PAST 2.01 (Hammer et al. 2001) and Systat 7.0 (SPSS Inc.). Non-parametric, monovariate analysis was performed as data were in general not normal distributed. Non-parametric analysis of variance (Kruskal-Wallis) tested which physicochemical parameters significantly $(P<0.05)$ contributed to the molecular detection of micro-organisms. Spearman rank correlation was applied to test relationships between percentages of individual phyla on the one hand and physicochemical parameters on the other hand. Significance levels were adjusted to correct for multiple testing, such that the false discovery rate was less than $10 \%$ (individual $P \sim 0.002$ or lower).

Multivariate analysis on clone abundances (Direito et al. 2011) and environmental data (Table 2) comprised principal 
coordinate analysis (PCoA), canonical correspondence analysis (CCA) and Mantel transformations. PCoA is an ordination technique to project high-dimensionality data sets on a few axes in reduced space. The Bray-Curtis similarity coefficient was calculated for species abundances to account for the many double-zeroes in the data sets. The projection of the sample positions on the PCoA axis was subsequently used in correlations with environmental data, providing an indirect gradient analysis. CCA is a direct gradient analysis, in which species abundances are considered to be a response to the environmental conditions; its ordination axes are linear combinations of the environmental variables. Species abundances were tested in the form of the relative phyla or class abundances of each of the three domains separately. Mantel transformation correlates two data matrices, e.g. a matrix with similarities in bacteria denaturing gradient gel electrophoresis (DGGE) profiles versus a matrix with similarities in Archaea DGGE profiles, to determine if they have the same structure.

\section{Results and discussion}

We have combined the analysis of ten selected samples that were analysed with various techniques concerning mineralogy composition, abundance of amino acids, PAHs and biota in order to perform correlation studies. The results are compiled in Tables 1 and 2 . The $\mathrm{pH}$ values are slightly alkaline and range from 7.5 to 10 (Orzechowska et al. 2011). Using a soil kit analysis (see 'Sample analysis' section) on-site we measured abundances of nitrates, $\mathrm{K}, \mathrm{P}$ and $\mathrm{Mg}$. The $\mathrm{K}$ values range from 140 to $250 \mathrm{ppm}$ and $\mathrm{Mg}$ concentrations of all samples are very low with values below a few $\mathrm{ppm}$. P abundances range from 5 to $100 \mathrm{ppm}$. Nitrate concentrations above $75 \mathrm{ppm}$ have been detected in samples P-2 and P-5 (from the Morrison Formation). In the Atacama Desert, there are large accumulations of nitrate (of atmospheric origin) because microbial denitrification is not occurring (Gómez-Silva et al. 2008). Nitrates are soluble in water and in deserts they are usually an indicator of low water influence.

\section{On-site and off-site summary}

Bulk X-ray diffraction and infrared spectroscopy of samples show common sedimentary mineralogy with all samples containing quantities of hydrated sulphate minerals and or phyllosilicates. Analysis of the clay fractions indicate that the phyllosilicates are interstratified illite-smectites (Kotler et al. 2011). Combining the clay fraction X-ray diffraction data with FT-IR spectra allowed tentative identifications of the smectite clay phases. The dominant smectites in the samples are montmorillonite and nontronite. The most common sulphate mineral in the samples is hydrated calcium sulphate (gypsum). Carbonates detected in the samples are variable in composition and include pure calcium carbonate (calcite), magnesium bearing calcium carbonate (dolomite), magnesium, iron and manganese bearing calcium carbonate (ankerite) and iron carbonate (siderite).

The organic content of the samples ranges from 1 to $5 \%$ (w/w) (Orzechowska et al. 2011). The concentration of PAHs in the soils has been determined by SPME and liquid extraction. SPME minimizes sample handling and preserves chemical integrity of the sample and can more efficiently extract 2- and 3-ring volatile PAHs compared with liquid extraction (Orzechowska et al. 2011). Naphthalene has been detected in all ten samples using this technique with concentrations between 3 and $20 \mathrm{ng} / \mathrm{g}$. The concentrations of other individual PAHs were measured and amount to $1-60 \mathrm{ng} / \mathrm{g}$ using both techniques (Orzechowska et al. 2011). These PAH concentrations are at least four orders of magnitude lower that those determined in some industrial soils. PAHs on surfaces are usually the result of atmospheric deposition, whereas PAHs in the subsurface are most likely derived from fossil organic matter. At low maturities cyclic structures are aromatized and at higher maturities lots of structures are forced into a stable aromatic configuration. Table 2 indicates that the PAH concentration is not correlated to cliff, surface or subsurface sample locations and it is overall low; a slightly higher concentration for several PAHs is measured in the Mancos Shale samples that host more organic matter (Orzechowska et al. 2011). The total detected PAH content of small 2- and 3-ring PAHs with the SPME technique shows a large range of variations across the samples from 14 to $98 \mathrm{ng} / \mathrm{g}$. The PAH distribution from the liquid extraction technique for 2-6-ring PAHs shows a narrower range from 38 to $57 \mathrm{ng} / \mathrm{g}$ (excluding the sample P10, where $116 \mathrm{ng} / \mathrm{g}$ are detected). This indicates a quite homogeneous PAH distribution of mid-size PAHs over the different sites, possibly due to Aeolian transport and delivery of these compounds.

The total amino acid content is highly heterogeneous between all the collected soil samples. Amino acids abundances are non-detectable for many samples. The most abundant amino acids detected in a few soil samples include L-valine, L-alanine, glycine L-leucine, L-aspartic and L-glutamic acid. These amino acids were also identified in other hot desert soils, such as those from Oman, Arequipa and Atacama (Martins et al. 2007; Peeters et al. 2009). Total concentrations of amino acids range from 280 to $4600 \mathrm{ppb}$, with the exception of Dakota/Oyster reef samples (P-13/P-14) that range from 17000 to $100000 \mathrm{ppb}$ (Martins et al. 2011).

Culture-independent molecular analyses directed at ribosomal RNA genes revealed the presence of all three domains of life (Archaea, Bacteria and Eukarya), but these were not detected in all samples (Direito et al. 2011). Spiking experiments revealed that the absence of life in some samples is due to the adsorption or degradation of DNA on the mineral surface. Bacteria were most frequently detected and showed high alpha(within a community) and beta-diversity (between communities). Members of the Actinobacteria, Proteobacteria, Bacteroidetes and Gemmatimonadetes phyla were found in the majority of samples. The alpha- and beta-diversity for Archaea was very low. For Eukarya, a diverse range of species was identified, such as fungi, green algae and several phyla of protozoa. Phylogenetic analysis revealed an extraordinary variety of putative extremophiles, mainly Bacteria but also Archaea and Eukarya. These included radioresistant, endolithic, chasmolithic, xerophilic, hypolithic, thermophilic, thermoacidophilic, 
psychrophilic, halophilic, haloalkaliphilic and alkaliphilic micro-organisms. In summary, the data revealed large differences in the occurrence and diversity of microbes over short distances, indicating the need for high-sampling frequency at similar sites (Direito et al. 2011).

\section{Correlation between environmental parameters and biota}

It was demonstrated that it was possible to perform a direct on-site DNA analysis by PCR at MDRS, situated in an extreme environment that functions as a model for preparation and optimization of techniques to be used for future Mars exploration (Thiel et al. 2011b). The data from in situ DNA analysis are compared with post-analysis data in Table 2 . Differences between PCRs performed on-site at MDRS (Thiel et al. 2011a) and post PCR analysis (Direito et al. 2011) are detectable in three of the six samples that were analysed by both methods. Thiel et al. (2011a) detected, in addition to Bacteria, also Eukarya and Archaea in sample P-2, and Bacteria in sample P-7, while Direito et al. (2011) detected Archaea in P-10 in addition to Bacteria and Eukarya. These differences might be explained by the use of different primer sets on the two PCR analyses. Additional field campaigns using a larger number of samples are needed to validate the comparison between on-site and off-site analyses.

Mineralogy influences microbial community structure and diversity (Boyd et al. 2007; Carson et al. 2009). Differences in clay and mineralogical composition were observed in MDRS samples. The Dakota Sandstone samples P-13 (surface) containing fossil oyster shells showed the clear identification of all three domains of life in on-site and off-site (post-analysis) data as well as the highest amino acid concentration of $100000 \mathrm{ppb}$. The subsurface sample P-14 that was collected at the same site in $15 \mathrm{~cm}$ depth shows strikingly different results, no positive PCR signal was observed by on-site or off-site measurements although an amino acid concentration of $17000 \mathrm{ppb}$ was determined. It cannot be excluded that the amino acids measured in the subsurface sample P-14 are due to contamination from the surface. However, the amino acid analysis of sample P-14 indicates the presence of $\mathrm{L}$-amino acids only which is an indication for recent biological processes; all other samples with amino acid detection indicate mixed L- and D-amino acid concentration suggesting that racemization has occurred over time and amino acids may be fossil remains.

The comparison of the extent of amino acid racemization and the relative amino acid composition provides a useful indication for the preservation of organic molecules. In fact, amino acids should undergo complete racemization in less than 1-10 million years (Bada et al. 1999). In addition, P-14 is the sample with the highest sulphate concentration (Kotler et al. 2011), which is known to preserve well amino acids (Aubrey et al. 2006). Samples P-5, P-6 and P-7 from the Morrison Formation show hardly a positive PCR signal and no amino acids could be extracted from those samples. Samples P-5 and P-6 were collected from a cliff (see Fig. 1) and have the largest clay mineral content of all measured samples with 23 and $33 \%$, respectively. The sample P-6 is characterized by a dark green to olive colour (green turf), indicating that this material was deposited under reducing conditions. The sample P-7 was collected in a riverbed.

Amino acids can be bound to clay by very strong ionic bonds in the interior lattice channels. Extraction of DNA is known to be challenging from clay-rich material (Henneberger et al. 2006). The correlation between the clay fraction and methods of organic extraction is an important subject for future investigations. Not all clays are the same, for example bentonite clays are formed during volcanic deposition events and codeposition of organic matter should not be associated with that process. However, incorporation of organic matter by post deposition may be possible. Continental shelf clays will have organic matter co-deposited because they are hydrodynamic equivalents. Nadeau and Reynolds (1981) concluded that the majority of the smectites found in the marine shales formed during the Cretaceous period from the western interior of North America were formed by the alteration of volcanic glass. Smectite can also precipitate directly in the pore spaces of sandstone and in weathering environments by the slow movement of water in arid to semi-arid regions (Berner 1971). The smectite to illite transition (I/S) serves as an indication of thermal maturity for organic matter in sedimentary basins. Water held in the expandable layer of smectites is released as the mineral is transformed to illite (non-expandable). Smectites have the property of being able to expand and contract while maintaining an intact two-dimensional crystallographic structure. During expansion the interlayer cation in the structure can be exchanged resulting in high cation-exchange capacities compared with other clay minerals (Moore \& Reynolds 1997). Figure 2 shows the variations of amino acids and biota as a function of clay mineral percentage. Although the samples from the Morrison Formation with highest clay fraction (P-5 and P-6, 23 and 33\% clay, respectively) show no amino acids and biota, sample P-10 from the Mancos Shale Formation with clay mineral content of $20 \%$ does show moderate abundances of amino acids ( $2300 \mathrm{ppb}$ ) and the presence of all biota in the post analysis cycle. Stoker et al. (2011) argue that the Mancos Shale Formation may preserve primary organic matter but in the Morrison Formation it was removed by oxidation and diagenesis. However, a very low recovery of DNA from spiked samples (from the Morrison Formation) was observed indicating that DNA is adsorbed and/or degraded in the original soil (Direito et al. 2011). These data indicate that not only the geological history and depositional environment of the region but also the exact clay mineral make-up (e.g. smectite/illite ratio) will both influence the amount of intrinsic organic material and the subsequent extraction potential of compounds such as amino acids and DNA from host matrices.

Non-parametric, monovariate analysis showed that samples in which micro-organisms could be observed after PCR amplification had a significantly lower content of small claysized particles $(<1 \mu \mathrm{m})$ (Orzechowska et al. 2011) than samples in which micro-organisms were not detected. These samples were also characterized by a significant higher spike recovery and yield of isolated DNA (Direito et al. 2011), while other environmental factors did not show differences. This analysis suggests that high content of small, clay-sized particles has a 
a log Amino Acids (AA) - Biota Index of Bacteria-Eukarya-Archaea

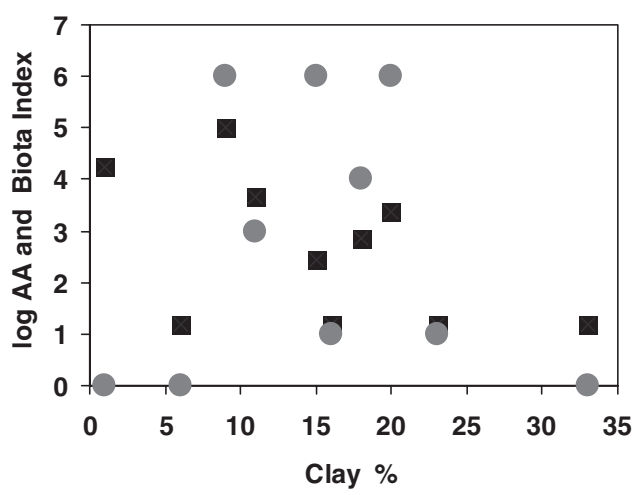

Fig. 2. Variations of amino acids and biota as a function of clay mineral percentage are displayed (data taken from Table 2). The amino acid concentrations $\mathrm{AA}$ in ppb show a large range from the sensitivity limit up to $100000 \mathrm{ppb}$ and are represented as log AA (or by $\log \mathrm{AA}=0$ when not detected). The biota detection is quantified by a Biota Index (from 0 to 6 ) adding each positive detection (+) of separate kingdoms (Bacteria, Eukarya and Archaea) using the two techniques, Power Soil and Fast-DNA (sum of + in three right columns in Table 2). The predominant detection of biota and amino acids occur in the mineral range with $9-20 \%$ clay. The sample with $1 \%$ clay $(\log \mathrm{AA}=4.2)$ is a subsurface sample obtained at $15 \mathrm{~cm}$ depth $(\mathrm{P}-14)$. $\mathrm{P}-14$ shows no detectable biota, but may have been contaminated by amino acids from the upper surface, as it was collected just below surface sample P-13 (highest in amino acids, $\log \mathrm{AA}=5$ ) (Martins et al. 2011). Geological history and clay composition influences the abundance of intrinsic organics and the extraction capability of organic and biological compounds (see 'Results and discussion' and 'Astrobiology field research in support of future Mars missions' sections).

negative effect on DNA recovery and consequently on the detection of micro-organisms. Likely, this relates to the strong nucleic acid adsorption capacity of clay particles (e.g. Saeki \& Sakai 2009), which have a relatively high surface to volume ratio compared with silt and sand. Therefore, for sensitive DNA-based methodologies, it is extremely important to apply and further optimize extraction methods that minimize adsorption of released DNA to soil particles during DNA isolation (Zhou et al. 1996; Herrera \& Cockell 2007).

No significant correlation was observed between amino acid content and DNA yield or detection of micro-organisms, see also Fig. 2. This is either related to different adsorption characteristics of amino acids and DNA or the occurrence of amino acids unassociated with cells. Different organic molecules persist for varying amounts of time once an organism dies. Amino acids can last longer than DNA (Sephton 2010).

PAHs and organic matter constitute potential sources of carbon for growth and survival of micro-organisms. However, PAHs and organic matter contents did not correlate with DNA yield or detection, which is in line with the clone library data (Direito et al. 2011). To our knowledge, there is no evidence for the microbial production of PAHs in desert soils. Microbes may catalyse PAHs degradation depending on the environmental conditions and the number and types of microbes.
Phylogenetic analysis gave only a few indications for sequences closest related to micro-organisms known to degrade hydrocarbons (Pandorea, Ralstonia, Pseudomonas and Rhodococcus) or sequences encountered in hydrocarbon polluted environments. Much of the organic matter is likely to be in the form of recalcitrant compounds that are difficult to use by microorganisms. PAHs have poor bio-availability, which often makes them persistent soil contaminants. They are low down the list of carbon sources for bacterial degradation targets.

The large differences between samples in microbial community structure, as revealed by DGGE profiles (Direito et al. 2011) and environmental data, respectively, was also revealed by PCoA on the clone library data of Direito et al. (2011); PCoA failed to reveal a clear grouping of samples (data not shown). Mantel transformation indicated that the bacterial, archaeal and eukaryotic communities were not significantly related to each other. Both indirect and direct gradient analyses did not reveal environmental parameters that significantly explained microbial community structure. A few significant correlations were observed between percentages of individual bacterial phyla and physicochemical parameters.

The relative occurrence of the phylum DeinococcusThermus was positively related with $\mathrm{pH}$, while the occurrence of the phylum Chlorofexi was positively related with PAH content, although this phylum is not known for its ability to degrade, or produce PAHs. The only mineral that revealed a relation with the occurrence of a particular group of microorganisms was carbonate. Carbonate content was positively correlated with the phylum Proteobacteria, but not to any of the individual classes within the Proteobacteria.

The examined samples were selected to cover a range of different environments in order to obtain broad insight into the biological and environmental heterogeneity at MDRS. While this clearly revealed a surprisingly large biodiversity, this sampling approach hampered relating the environmental chemistry to the microbial community structure. Current landing site strategies for future Mars missions and in particular scenarios for MSR landing sites argue for high diversity of samples for in-situ analysis and sample return as summarized in the recommendations of the recent workshop on landing site strategies for exploration missions (Zegers et al. 2011). On Mars heterogeneity in the mineral composition of rocks has been measured at Gusev Columbia Hills and Meridiani Planum, as investigated by the instruments on the MER rovers (Klingelhofer et al. 2004; Squyres et al. 2004).

\section{Comparison with the subsurface sampling campaign at MDRS}

A subsequent mission performed in November 2009 and March 2010 (see Stoker et al. 2011 this issue) collected and analysed an additional set of subsurface samples. In their case, a soil core was acquired from each of the four geologic units in the MDRS area identified by reference to the regional geologic map of the Salina Quadrangle, Utah. Each core was acquired down to bedrock and was at least $1 \mathrm{~m}$ deep. We refer to these samples here as the $\mathrm{S}$ series (to allow them to be distinguished from samples P-1 to P-14 in Tables 1 and 2). They include samples from: (1) two locations in Mancos shale (Tununk 
Table 3. Soil core locations and parameters of the subsurface DOMEX campaign (Stoker et al. 2011). The subsurface samples were collected in a subsequent campaign from the three geological units within the MDRS area. These samples are related in geological context and regional area to samples P-1 to P-14. Similarities are evidenced by the higher organic content of Mancos Shale soils. Both $S$ and $P$ series samples do not show a correlation of microbial numbers and diversity with either organic content or mineralogy, see 'Results and discussion' section

\begin{tabular}{lllllll}
\hline Sample & Coordinates & Formation & Core length $(\mathrm{cm})$ & $\mathrm{pH}$ & Phosphorus (ppm) & P series counterpart \\
\hline S 1 & $38.351142^{\circ}, \mathrm{W} 110.856056^{\circ}$ & Mancos/Tunuck & 127.64 & 7.92 & 6.4 & $\mathrm{P} 1$ \\
S 2 & $38.397556^{\circ}, \mathrm{W} 110.794833^{\circ}$ & Morrison & 55.25 & 8.46 & 5.8 & $\mathrm{P} 2 / \mathrm{P} 3$ \\
S 3 & $38.394744^{\circ}, \mathrm{W} 110.797718^{\circ}$ & Dakota & 71.75 & 7.83 & $<3$ & $\mathrm{P} 13 / 14$ \\
S 4 & $38.501426^{\circ}, \mathrm{W} 110.926809^{\circ}$ & Mancos/Ferron & 69.22 & 8.43 & $<3$ & $\mathrm{P} 8 / \mathrm{P} 10$ \\
\hline
\end{tabular}

member and Blue Gate-Ferron Sandstone border), from widely separated locations denoted S1 and S4, (2) a Morrison Formation denoted S2, (3) a Dakota Formation denoted S3 and (4) a Summerville Formation denoted S5 (see Table 3). While these samples were not collected in the same locations as samples P-1 to P-14, they are related by geologic context and regional area. These soils were subjected to a suite of analyses that overlap with those performed on samples P-1 to P-14. All the soils except that of the Summerville unit have counterparts in P-1 to P-14 (see Table 3). There are important similarities and differences.

Similarities: All soils except that from the Summerville unit (denoted S1-S4; Stoker et al. 2011) are rich in phyllosilicates and sulphates. In both the $\mathrm{S}$ and $\mathrm{P}$ series, organics were extracted. Different methods were used in each case and that may in part be responsible for quantitative differences observed in the total organic concentration.

In the $\mathrm{S}$ series, the method (Wakely-Black) uses liquid extraction of the easily oxidized organic fraction with yielded lower yield than the combustion method used for the $\mathrm{P}$ series. Still, the same pattern is seen where the highest organic fraction is observed in the Mancos shale soils S1 and S4, a lower, but still significant fraction of organics is observed in the Dakota sample (S3) and no organics are detected in the Morrison Formation soils (Stoker et al. 2011).

Since both the Morrison Formation and Mancos Formation are shales comprised of smectite minerals (montmorrillonite, nontronite, illite along with other minerals are detected in both of the units), the mineralogy is unlikely to be responsible for the differences in organic make-up. The geologic history of the respective units is more likely the culprit. In the case of the Mancos Formation, the depositional environment was a deep, anoxic sea where organics were richly preserved to begin with. In the case of the Morrison Formation, the depositional environment was a flood plain with short periods of deposition interspersed with long ones of oxidation. The floods carried large biomass loads of fauna and flora, and examples of these are preserved in various locations as petrified logs and fossil dinosaur bones. However, subsequent diagenesis has replaced the carbon from these sources with other minerals such as silicate and phyllosilicate minerals.

Differences: Sulphates are much more abundant than carbonates in all the $\mathrm{S}$ series samples. The carbonate ion was too low to be detected by the methods used to analyse $\mathrm{S}$ series soils. Sulphate correlates with $\mathrm{Na}$ rather than $\mathrm{Ca}$ or $\mathrm{Mg}$, suggesting a dominance of sodium sulphate minerals. Carbonate is not detected in any of the soils of the Mancos or Morrison Formation (although carbonate rock examples were found near the soil cores). Likely those samples collected at depth are below the carbonate soil horizon.

Microbial numbers and distributions were determined in the deepest depth soil core from each sample in the $\mathrm{S}$ series. Microbes are found in all the cores. The numbers vary by a factor of 6 between the highest and the lowest microbial number: highest: $1.8 \times 10^{7}$ and lowest: $3 \times 10^{6}$ cells $/ \mathrm{ml}$. These values are similar to measurements from the Atacama Desert (Connon et al. 2007; Lester et al. 2007; Bonnacorsi \& McKay 2008). DNA concentration measurements for the $P$ series were successful for two samples. Thiel et al. (2011a) measured $0.088 \mu \mathrm{g} / \mathrm{ml}$ for sample P-2 from the Morrison Formation and $5.04 \mu \mathrm{g} / \mathrm{ml}$ for sample P-13 from the Dakota Formation using fluorescence measurements (see 'Sample analysis' section).

Both $\mathrm{S}$ and $\mathrm{P}$ series show that microbial numbers and diversity does not appear to be correlated with either organic content or mineralogy. Instead, the dominant factor in bacterial number may be soil porosity and lower small, clay-sized particle content. The ability of soils to hold water may strongly influence the microbial numbers. Since clay minerals respond differently to humidity with the smectite group showing considerable expansion and retention of water and cations compared with the non-expandable clay minerals such as illite, the exact composition of the clay fractions can be an important factor.

The mixed layer illite/smectites found in the MDRS samples indicate that although some of the clay minerals present can contribute to the environmental conditions necessary to facilitate microbial growth (e.g. expandability and high cation exchange potential), the inferred predominance of illite in these samples may be an important factor when correlating clay minerals and the biological data (Kotler et al. 2011).

\section{Astrobiology field research in support of future Mars missions}

The search for extinct or extant life on Mars or organic material is one of the main goals of future surface missions developed during this decade (e.g. Westall et al. 2000; ten Kate 2010). The Mars Exploration Program Analysis Group (MEPAG) lists as its first goal: Determine if life ever arose 
on Mars (http://mepag.jpl.nasa.gov/). The Viking landers were the only spacecraft equipped with a biological and a molecular analysis experiment (Soffen 1977). No organic matter and no proof of life were found although detection limits of the GC-MS were in the ppb range (Biemann 1979). It is possible that the Viking GC-MS failed to detect certain types of organic material present in the Martian soil (Benner et al. 2000; Glavin et al. 2001; Navarro-González et al. 2010).

\section{Searching for organic material on Mars}

Scientists are at odds when it comes to evaluate the chances for detecting life on Mars. Past conditions of Mars may have allowed life to develop. In particular, the earliest liquid-water rich era would present the most habitable conditions (Sephton 2010). Surface investigations of minerals on Mars indicate high salt concentrations and acidic conditions that limit the efficient production of organic material (Tosca et al. 2008). DNA is unstable under acidic conditions, owing to depurination-induced degradation of DNA. Endogenous production of organic material on Mars may have proceeded through similar mechanisms as suggested for the early Earth in the presence of energy sources such as lightning, UV and particle radiation, atmospheric shocks, etc. (Chyba \& Sagan 1992; Ehrenfreund et al. 2006). Life on Earth originated approximately 3.5 billion years ago (Derenne et al. 2008; Westall 2009) and has adapted to nearly every explored environment. Recent discoveries have shown that life can exist in extreme environments including hydrothermal vents, in deserts and in ice lakes in Antarctica. Such a wide distribution of life is not expected on Mars. Although conditions on ancient Mars may have been favourable for life, an overall low biomass restricted to localized areas is more probable. The habitability of the Phoenix Landing site has recently been investigated (Stoker et al. 2010). Cometary and meteoritic impacts in the first 700 million years after solar system formation have delivered large amounts of organic molecules to the young planets (Chyba \& Sagan 1992). Meteoritic infall to the Martian surface by small bodies and their fragmented dust is estimated to be $240 \times 10^{3} \mathrm{~kg}$ per year (Flynn 1996).

Today, the Martian surface is cold, dry and hostile. A combination of solar ultraviolet radiation and oxidation processes in the soil are destructive to organic material and life on and close to the surface. The atmosphere of Mars allows solar light down to $\sim 190 \mathrm{~nm}$ to reach the surface of the planet (see Patel et al. 2002, for a model of the Martian UV environment). Below the surface galactic cosmic rays (GCR) and solar energetic protons (SEP) can efficiently destroy organic and biological material over geological timescales (e.g. Dartnell et al. 2007).

The destruction of organic matter on the surface of Mars may follow diurnal cycles and likely proceeds during night time when monolayers of water adsorb on the surface minerals and react with radicals that have been formed during day time by UV radiation processing in the Martian atmosphere. Water and radicals in combination with active mineral surfaces then drive an active chemistry and oxidation processes that lead to destruction of organic material (Quinn et al. 2005). Oxidizing species may also be created directly in the soil, by Fenton-type reactions (Liang et al. 2006) and superoxide radicals (Yen et al. 2000). Organic material arriving on the Martian surface via small bodies may be converted to carboxylic acid derivatives (Benner et al. 2000). The large number of laboratory experiments performed in atmospheric Mars chambers has provided supporting material to our understanding of organic degradation and the viability of micro-organisms on Mars. The effects of UV and ionizing radiation, dust plasma, diurnal variations and oxidative processes on organic and biological matter have been studied by various groups worldwide (see ten Kate 2010 for a review). The consensus of the scientific community is that drilling to the subsurface and analysing fresh samples from 1 to $2 \mathrm{~m}$ depth will be a prerequisite (such as planned for Exomars 2018).

Future Mars missions will search for past and present life with the help of instruments that can identify tracers for life, namely organic molecules and fossils hidden in rocks and in the Martian subsurface. Hereditary molecules such as DNA would provide a definitive proof of life and could be amplified with appropriate instrumentation. The scientific consensus is that the search for extinct life may be more successful than looking for extant life. Whereas the detection of fossils would indicate a biotic origin and represent an indication for life, other organic compounds, such as amino acids and PAHs may be abiotic in origin and be delivered by small bodies and their fragments. Aliphatic hydrocarbon chains usually indicate life with the exception of isomerically diverse aliphatic materials that are better indicators of abiotic processes.

On a weight basis, amino acids (as building blocks of proteins) are generally the most abundant single class of molecules in a bacterial cell. Proteins take up $1.6 \times 10^{-13} \mathrm{~g} / \mathrm{cell}$ of the dry weight composition of Escherichia coli (Brock et al. 1984), which amounts to more than $50 \%$ of its biomass. Other cell material such as nucleobases associated with DNA and RNA are less abundant (up to 25\%) and lipids take up less than $10 \%$ of the dry weight composition of $E$. coli. Also the stability of amino acids at low $\left(0^{\circ} \mathrm{C}\right)$ and high temperature $\left(100^{\circ} \mathrm{C}\right)$ is superior compared with other cell compounds (e.g. Ehrenfreund et al. 2006).

$\mathrm{PAHs}$ are observed widely distributed in galactic and extragalactic regions and aromatic material (in the gas phase and as solid) is the most abundant organic material in the universe (Tielens 2008). PAHs are composed of aromatic rings and characterized by high stability against radiation, in particular when in peri-condensed (compact) form. The insoluble carbon fraction of carbonaceous meteorites contains predominantly solid aromatic carbon networks; soluble PAHs are also found in concentrations of $\sim 50 \mathrm{ppm}$ (Sephton 2002). The abundance and stability of PAHs and their ubiquitous presence in space environment make them interesting target molecules.

A molecular target list according to biological significance has recently been prioritized that represents molecules from meteoritic input, fossil organic matter, extant organic matter and contamination. Among the high priority targets are amino acids, small PAHs (e.g. naphthalene), carboxylic acids, hydrocarbons (such as pristine and phytane), hopanes and others 
(Parnell et al. 2007). The preservation potential of biomacromolecules has been considered by Tegelaar et al. (1989) and Sephton (2010). Lipopolysaccharides are among the species that have the highest preservation potential. Hopanes are among the most recalcitrant biomarkers present in fossil organic matter (Tritz et al. 1999) and therefore a priority target in the search for extinct life.

\section{Instrumentation developed for organic detection on Mars}

In this decade, currently two missions are planned that will search for biomarkers and small organic compounds on the Martian surface. The upcoming MSL scheduled for launch in the fall of 2011 is equipped with the Sample Analysis at Mars (SAM) instrument suite. A primary focus of SAM will be the detection and identification of organic molecules by way of thermal volatilization GC-MS. Some of SAM's sample cups are filled with derivatization agents that will dissolve organics from the soil before pyrolysis and make them more volatile to enhance organic detectability by the GC-MS (http://science. gsfc.nasa.gov/699/marsSAM.shtml).

The Mars Organic Molecule Analyzer (MOMA) instrument is part of the Exomars 2018 payload and is able to detect and identify molecular species at low concentrations (that is ppb to ppt) (http://www.mps.mpg.de/en/projekte/exomars/moma/ index_print.html). One application of MOMA is the use of a MOMA GC-MS for the detection of volatile molecules in atmospheric and sedimentary material. The other option for less volatile molecules is to produce ions by high power laser pulses that desorb them from their embedding solid sample matrix. The second instrument on Exomars 2018 that is dedicated to the search for biomarkers is the Life Marker Chip (LMC) (http://www.lionixbv.nl/about/r_lmc.html). The LMC instrument has the potential to unambiguously detect past or present life on Mars, if it ever existed or still exists. This instrument relies on novel antibody micro-array technology; when immobilized to a surface antibodies can be used as receptors to capture specific molecules (Parnell et al. 2007). LMC is capable of detecting a wide variety of different biomarkers from a liquid sample (Court et al. 2010).

\section{EuroGeoMars 2009 campaign: astrobiology and habitability studies}

The MDRS EuroGeoMars 2009 campaign covered a large spectrum of technology and research objectives described by Foing et al. (2011). In-situ and post-analysis investigations (on-site and off-site) of habitability were optimized to quantify organic molecules that are targeted by current planetary organic detection instruments, such as amino acids and PAHs.

The organic detection instruments on future Mars missions such as SAM, MOMA and the LMC are capable of detecting amino acids and small PAHs. In this context, we used SPME that targets in particular the detection efficiency of 2-3 ring PAHs (Orzechowska et al. 2011). Whereas PAH concentrations and in particular naphthalene (likely of atmospheric origin) could be measured in all samples, the abundances did not exceed ng/g levels. Amino acids levels showed a larger heterogeneity; only four samples showed abundances in the ppm level (Martins et al. 2011) similar to results obtained from the Oman and Atacama Desert (Martins et al. 2007; Peeters et al. 2009). Measurements of the microbial biota were performed on-site in the MDRS habitat right after sample collection (Thiel et al. 2011a) and during a post-analysis cycle using different methods (Direito et al. 2011). Although the Utah desert environment is an extreme dry environment with a continental range of temperature, a large heterogeneity was identified within the microbial community.

There are several factors that will play an important role in the search for organic material on Mars. Results from the EuroGeoMars 2009 campaign show that samples in which micro-organisms could be observed after PCR amplification, had significantly lower small (clay-sized) particle content than samples in which micro-organisms were not detected. Amino acid abundance may reflect the ability of the host sediment to receive and retain water, thereby hosting microbial life. However, no significant correlation was observed between amino acids and DNA yield or positive PCR signals. To test whether the low-DNA contents were due to low biomass content or due to low extraction efficiencies, several of the clayrich soil samples were spiked with a known quantity of DNA. DNA extraction and quantification of many of the spiked clayrich samples showed a very low recovery rate (Direito et al. 2011). The compiled data indicate that the extraction efficiency of amino acids and DNA material from the mineral host matrix will strongly depend on the depositional environment of the minerals (geological history), the degree of illitization of the clay and the instrument performance. Although soils of particular mineral composition are known to better preserve organic molecules and provide a comfortable environment for microbes - the same mineral matrix may provide a challenge for organic/life detection instruments.

Clays are known to adsorb DNA (e.g. Saeki \& Sakay 2009) by ligand exchange: the DNA phosphate groups may bind via ligand exchange to $\mathrm{OH}$ groups of iron, aluminium oxide or minerals, including phyllosilicates. Clays have also been proposed as material on the early Earth where biomolecules could have been accumulated and reacted to form the first primitive cells (Ponnamperuma et al. 1982, Cairns-Smith \& Hartman 1986, Ertem \& Ferris 1998). Adsorption and binding of pure DNA to clay minerals and humic substances protect the DNA molecule against enzymatic degradation (Crecchio \& Stotzky 1998).

Adsorption and binding of dirty DNA (characterized by the presence of cellular wall debris) on montmorillonite and kaolinite and their transforming ability in comparison with pure DNA was investigated and showed that dirty DNA was adsorbed to clay minerals and protected against degradation by nucleases (Pietramellara et al. 2007). Bacteria are more protected from predators (e.g. protozoan predation) in finetextured soils than in coarse-textured soils (Rutherford \& Juma 1992). Recent results show that low pore connectivity may even contribute to high bacterial diversity in soil (Carson et al. 2010).

The different geological history on Mars (lack of widespread tectonic recycling and igneous lithological diversity) and the 
combination of impacts, volcanism and hydrologic cycle lead to a finite number of major clay-forming processes and a different clay cycle on early Mars (Tosca \& Hurowitz 2011). The majority of Martian clay deposits are consistent with $\mathrm{Mg} / \mathrm{Fe}$-rich varieties (Murchie et al. 2009). Milliken et al. (2011) have analysed the diagenesis of clay material in the landing site regions for the MSL rover. All potential landing sites show evidence for clay minerals, but with potential differences. Applying a two-parameter calculation using laboratory spectra and comparison with orbiter data, Milliken et al. (2011) concluded that mixed-layered chlorite/smectites are predominant and that pure smectites are rare on Mars.

Phyllosilicate outcrops are a main target of future missions to Mars for the search of organic material (e.g. Zegers et al. 2011). However, adsorption of biological material can be an issue that has been recognized and needs to be addressed in future experiments (Henneberger et al. 2006). Interactions between DNA and the environmental sample can greatly complicate the procedure (e.g. He et al. 2005) and DNA-clay binding can increase at acidic pH (Khanna \& Stotzky 1992). The Urey instrument, an advanced in situ organic and oxidant detector, originally proposed for the Exomars mission, developed a sub-critical water extraction system to separate and concentrate the organic compounds from the mineral matrix (Aubrey et al. 2008). Due to the potential difficulty of extracting organic matter from mineral matrices because of adsorption and/or potential substitution within the mineral structure (Kotler et al. 2009), direct laser desorption and ionization techniques (such as those being explored for the Exomars mission) and related techniques for sample return missions (Yan et al. 2007; Kotler et al. 2008; Richardson et al. 2008) may provide the needed methods to release and detect potential biosignatures.

The results and lessons learned from the EuroGeoMars 2009 campaign confirm that the successful in situ detection of organics on Mars will involve a complex sequence of interdependent processes and trades. Figure 3 shows a flow diagram that outlines events that can be expected to contribute to the ability to recover organic compounds on Mars. For Mars exploration, top-level trades incurred during site selection may limit the ability to access the most desirable regions with a high probability for the preservation of organic compounds. Once a science platform is landed on Mars, the search for organics can be further impeded by sample processing and delivery constraints, as occurred on Mars with the Viking GC-MS and Phoenix thermal evolved gas analyser (Ming et al. 2009; Navarro-González et al. 2010).

The EuroGeoMars 2009 campaign was not limited by sample access as may be the case on Mars (e.g. need for drilling) and appropriate precautions were taken to prevent sample contamination (e.g. aseptic collection and storage). Additionally, the environmental parameters that result in the degradation of organic compounds are less extreme at the Utah site than they are in Atacama Desert and on Mars. Yet, even with unrestricted access to areas with high organic preservation potential (e.g. clay-rich materials) the recovery of organics is challenging. The level of organic material present in clay will strongly depend on its deposition history, diagenesis and specific composition.

Even with analytical accuracy and sensitivity of Earth-based laboratory experiments that involve solvent extraction or amplification neither DNA nor amino acids could be detected in a number of samples. Instrumentation on future Mars missions is limited by extraction precision compared with Earth-based techniques. Therefore, apart from a thorough habitability assessment (by remote mapping) of possible landing sites, a systematic investigation after landing using context instruments is necessary. Before organic detection measurements are performed it will be crucial to confirm if the instrument performance is compatible with the selected target sample.

As shown at the bottom of Fig. 3, our result reinforces the continuing need for ground truth studies to enable the successful detection and characterization of organics on Mars. An interdisciplinary preparation phase for future Mars missions is crucial to better understand the processes that may alter organic matter. Mars laboratory simulations that take into account the effects of UV and ionizing radiation, atmospheric reactions, aridity, temperature conditions, surface oxidation, salinity and acidity and Aeolian processes need to be undertaken and compiled in a database to determine how the preservation potential of molecules influences the record that can be observed. Each molecule reacts differently to the individual processes relevant to Mars climate and conditions and is preserved differently in respective environments. Another important aspect is the preservation of organics during analysis, e.g. in the presence of perchlorate (Navarro-González et al. 2010) and other potential Martian soil oxidants. Contamination control for organic detection instruments represents still one of the most challenging aspects of Mars missions with astrobiology context. Analogue field research and method validation in desert and extreme environments will improve techniques and protocols that can overcome analytical and other constraints encountered during Mars exploration.

\section{Conclusion and future perspectives}

The search for organic material and biosignatures on Mars is a highly complex endeavour. Several endogenous pathways for the production of organic matter on Mars have been proposed (e.g. Chyba \& Sagan 1992; Bada \& McDonald 1995). Influx of organic material from small bodies must have occurred with certainty (Flynn 1996).

Although oxidative and radioactive processes on the Martian surface are destructive to any biological compounds, the cold and dry climate on Mars may preserve organic matter in the subsurface, even in old terrain when spared from regional metamorphism. As discussed in 'Results and discussion' and 'Astrobiology field research in support of future Mars missions' above and summarized in Fig. 3, the successful hunt for organics will be a trade off between several parameters, including the original organic molecule concentrations, the preservation potential, extractability and the instrument performance. 


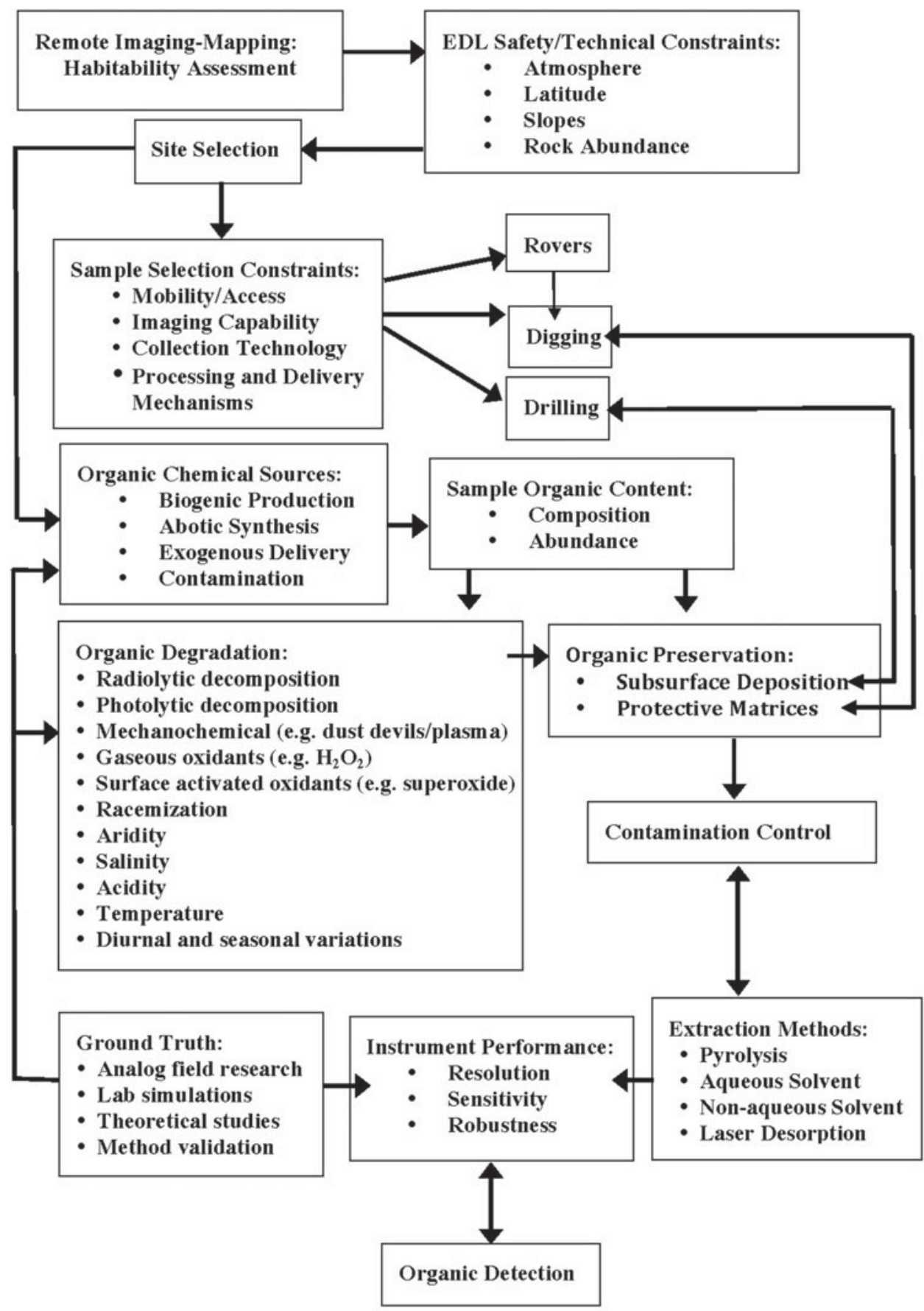

Fig. 3. Critical aspects and constraints for organic and life detection on Mars.

When deploying organic detection instruments on Mars, considering only the geological context and the history of regional aqueous processes for landing site selection may be insufficient. The intrinsic and external sources of possible organic materials needs to be better constrained. Regions where organic material could be formed and preserved over long time scales, such as environments that witness aqueous mineral processing (presence of phyllosilicates) may not be the best locations for organic detection because frequently instrument performance is inadequate to analyse samples collected in such terrains. As discussed in 'Astrobiology field research in support of future Mars missions', clays are known to strongly absorb and bind organic molecules often preventing extraction by even sophisticated laboratory methods. Field research conducted during the EuroGeoMars 2009 campaign shows the need to further optimize extraction procedures to analyse biomarkers and organic molecules in future sampling campaigns. Methods have to be developed that can release adsorbed biological compounds such as amino acids and DNA during the extraction process from soils. In order to obtain 
better insight into the microbial community structure, and the factors dictating the composition of microbial communities, analogue research is vital and probably most efficient through replicated sampling along an environmental or distance gradient. Nutrient source and transport studies (e.g. biolimiting nutrients such as $\mathrm{P}$ and $\mathrm{N}$ ) in desert regions as well as the investigations of water availability as it relates to sediment porosity may provide insights into the possible distribution of life on Mars. Additionally, methods have to be elaborated to distinguish biologic from non-biologic organic matter and fossil organic matter from recent remains.

If searches for low molecular weight organics, using current technologies are not successful, the search for larger (more stable) organic structures may be more rewarding. The predominant carbon fraction of meteorites is composed of a macromolecular network (Alexander et al. 2007). Such a material is rather resistant to radiation and temperature variations and should be present on Mars, possibly as metastable fragments. Additionally, with appropriate techniques, it may be possible to detect fluorescent fingerprints of extremophilic and photosynthetic microbes that are remnants of microbial life on Mars (Dartnell et al. 2010). In the absence of organics and biomarkers, minerals may still preserve evidence of former life processes. These research avenues will require the development of new instruments for the characterization of macromolecular carbon and for in situ measurements of the isotopic composition of organic matter, minerals and rocks.

Scientific work on the issues mentioned above will allow us to make more informed decisions on how to develop and execute successful organic detection strategies and techniques on Mars. An important criterion for future landing site scenarios is to define geological important terrain that is compatible with the organic detection instrument capabilities. Earth-based field and laboratory research will be vital in the preparation phase for future space missions to define an integrated suite of instruments that allows multiple and complementary measurement approaches that can successfully identify organic matter on Mars prior to MSR missions.

\section{Acknowledgements}

Pascale Ehrenfreund is supported by the NASA Astrobiology Institute (NAI). Zita Martins is supported by the Royal Society. Zita Martins and Mark A. Sephton acknowledge the Science and Technology Facilities Council (STFC) for financial support. Susana Direito and Wilfred Röling are supported by NWO grant ALW-GO- PL/07-11 ('Molecular detection of life on Mars'). Pascale Ehrenfreund and Susana Direito acknowledge financial support from ESA grant (ground-based facilities): 'Simulations of organic compounds and micro-organisms in Martian regolith analogues: SocMar'. The EuroGeoMars 2009 campaign was organized and supported by the International Lunar Exploration Working Group (ILEWG), NASA Ames Research Center and ESA/ ESTEC. We acknowledge the contribution of the EuroGeoMars 2009 campaign crew, the mission support team and ExoGeoLab pilot project. This research was conducted in the framework of the Mars Express Recognized Cooperating Laboratory for geochemistry.

\section{References}

Alexander, C., Fogel, M., Yabuta, H. \& Cody, G.D. (2007). The origin and evolution of chondrites recorded in the elemental and isotopic compositions of their macromolecular organic matter. Geochim. Cosmochim. Acta 71, 4380-4403.

Ansdell, M., Ehrenfreund, P. \& McKay, C. (2011). Stepping stones toward global space exploration. Acta Astronaut. 68, 2098-2113.

Arvidson, R.E., Ruff, S.W., Morris, R.V., Ming, D.W., Crumpler, L.S., Yen, A.S., Squyres, S.W., Sullivan, R.J., Bell, J.F., Cabrol, N.A. et al. (2008). Spirit Mars rover mission to the Columbia Hills, Gusev Crater: mission overview and selected results from the Cumberland Ridge to Home Plate. J. Geophys. Res. 113, E12S33.

Aubrey, A., Cleaves, J., Chalmers, J., Skelley, A., Mathies, R., Grunthaner, F., Ehrenfreund, P. \& Bada, J. (2006). Sulfate mineral and organic compounds on Mars. Geology 34, 357-360.

Aubrey, A.D., Chalmers, J.H., Bada, J.L., Grunthaner, F.J., Amashukeli, X., Willis, P., Skelley, A.M., Mathies, R.A., Quinn, R.C., Zent, A. et al. (2008). The Urey instrument: an advanced in situ organic and oxidant detector for Mars exploration. Astrobiol., Spec. In Situ Instrum. Edn, 8, 583-597.

Bada, J.L. \& McDonald, G. (1995). Amino acid racemization on Mars; implications for the preservation of biomolecules from an extinct Martian biota. Icarus 114, 139-143.

Bada, J.L., Wang, X.S. \& Hamilton, H. (1999). Preservation of key biomolecules in the fossil record: Current knowledge and future challenges. Philos. Trans. R. Soc. Lond., Ser. B. Biol. Sci. 354, 77-87.

Benner, A., Devine, K., Mateeva, L. \& Powell, D. (2000). The missing organic molecules on Mars. Proc. Nat. Acad. Sci. U.S.A. 97 (6):2425-2430.

Berner, R.A. (1971). Principles of Chemical Sedimentation. 240 pp. McGrawHill, New York.

Biemann, K. (1979). The implications and limitations of the findings of the Viking organic analysis experiment. J. Mol. Evol. 14, 65-70.

Bishop, J.L., Saper, L., Beyer, R.A., Lowe, D., Wray, J.J., McKeown, N.K. \& Parente, M. (2011). Possible sedimentary features in phyllosilicatebearing rocks at Mawrth Vallis, Mars. In 42nd Lunar and Planetary Science Conference, Woodlands, Abstract No. 2374.

Bonnacorsi, R. \& McKay, C.P. (2008). Total biomass and organics along a N-S moisture gradient of the Atacama region, Chile. In Lunar and Planetary Science Conference, Abstract. 1489.

Borst, A., Peters, S., Foing, B.H., Stoker, C., Wendt, L., Gross, C., Zavaleta, J., Sarrazin, P., Blake, D., Ehrenfreund, P. et al. (2010). Geochemical Results from EuroGeoMars MDRS Utah 2009 Campaign. LPI.41, 2744.

Boyd, E.S., Cummings, D.E. \& Geesey, G.G. (2007). Mineralogy influences structure and diversity of bacterial communities associated with geological substrata in a pristine aquifer. Microbial. Ecol. 54, 170-182.

Boynton, W.V., Ming, D.W., Kounaves, S.P., Young, S.M., Arvidson, R.E., Hecht, M.H., Hoffman, J., Niles, P.B., Hamara, D.K., Quinn, R. et al. (2009). Evidence for calcium carbonate at the Mars Phoenix landing site. Science 325(5936), 61-64.

Brock, T.D., Smith, D.W. \& Madigan, M.T. (1984). Biology of Microorganisms, 4th edn, pp. 14-93. Prentice-Hall International Inc., Englewood Cliffs, NJ, USA.

Cairns-Smith, A.G. \& Hartman, H. (eds) (1986). Clay Minerals and the Origin of Life, 193 pp. Cambridge University Press, Cambridge.

Carson, J.K., Campbell, L., Rooney, D., Clipson, N. \& Gleeson, D.B. (2009). Minerals in soil select distinct bacterial communities in their microhabitats. FEMS Microbiol. Ecol. 67, 381-388.

Carson, J.K., Gonzalez-Quiñones, V., Murphy, D., Hinz, D., Shaw, J.A. \& Gleeson, D.B. (2010). Low pore connectivity increases bacterial diversity in soil. Appl. Environ. Microbiol. 76(12), 3936-3942. 
Carter, J., Poulet, F., Ody, A., Bibring, J.-P. \& Murchie, S. (2011). Global distribution, composition and setting of hydrous minerals on mars: a reappraisal. In 42nd Lunar and Planetary Science Conference, Woodlands, Abstract no. 2593.

Chan, M.A., Beitler, B., Parry, W.T., Ormö, J. \& Komatsu, G. (2004). A possible terrestrial analogue for haematite concretions on Mars. Nature 429, 731-734.

Chevrier, V. \& Mathé, P.E. (2007). Mineralogy and evolution of the surface of Mars: a review. Planet. Space Sci. 55, 289-314.

Chyba, C. \& Sagan, C. (1992). Endogenous production, exogenous delivery and impact-shock synthesis of organic molecules: an inventory for the origins of life. Nature 355, 125-132.

Clarke, J. \& Stoker, C. (2011). Concretions in exhumed channels near Hanksville Utah: implications for Mars. Int. J. Astrobiol. 10, 161-175.

Connon, S.A., Lester, E.D., Shafaat, H.S., Obenhuber, D.C. \& Ponce, A (2007). Bacterial diversity in hyperarid Atacama Desert soils. J. Geophys. Res. 112, G04S17.

Court, R.W., Baki, A., Sims, M., Cullen, D. \& Sephton, M.A. (2010). Novel solvent systems for in situ extraterrestrial sample analysis. Planet. Space Sci. 58, 1470-1474.

Crecchio, C. \& Stotzky, G. (1998). Binding of DNA on humic acids: effect on transformation of B. subtilis and resistance to DNase. Soil Biol. Biochem. 30, 1061-1067.

Dartnell, L.R., Desorgher, L., Ward, J.M. \& Coates, A.J. (2007). Martian sub-surface ionising radiation: biosignatures and geology. Biogeosci. Discuss. 4(1), 455-492.

Dartnell, L.R., Storrie-Lombardi, M. \& Ward, J.M. (2010). Int. J. Astrobiol. 9(4), 245-257.

Derenne, S., Robert, F., Skrzypczak-Bonduelle, A., Gourier, A., Binet, L. \& Rouzaud, J.N. (2008). Molecular evidence for life in the 3.5 billion year old Warrawoona Chert. Earth Planet. Sci. Lett. 272, 476-480.

Direito, S.O.L., Ehrenfreund, P., Marees, A., Staats, M., Foing, B. \& Röling, W.F.M., (2011). A wide variety of putative extremophiles and large beta-diversity at the Mars Desert Research Station (Utah). Int. J. Astrobiol. 10, 191-207.

Ehrenfreund, P., Rasmussen, S., Cleaves, J. \& Chen, L. (2006). Experimentally tracing the key steps in the origin of life. Astrobiology 6 (3), 490-520

Ertem, G. \& Ferris, J.P. (1998). Formation of RNA oligomers on montmorillonite: site of catalysis. Orig. Life Evol. Biosph. 28, 485-499.

Flynn, G.J. (1996). The delivery of organic matter from asteroids and comets to the early surface of Mars. Earth Moon Planets 72, 469-474.

Foing, B.H., Stoker, C., Zavaleta, J., Ehrenfreund, P., Thiel, C., Sarrazin, P., Blake, D., Page, J., Pletser, V., Hendrikse, J. et al. (2011). Field astrobiology research in Moon-Mars analogue environment: instruments and methods. Int. J. Astrobiol. 10, 141-160.

Formisano, V., Atreya, S., Encrenaz, T., Ignatiev, N. \& Giuranna, M. (2004). Detection of methane in the atmosphere of Mars. Science 306, 1758-1761.

Glavin, D.P., Schubert, M., Botta, O., Kminek, G. \& Bada, J.L. (2001). Detecting pyrolysis products from bacteria on Mars. Earth Planet. Sci. Lett. 185, 1-5.

Gómez-Silva, B., Rainey, F.A., Warren-Rhodes, K.A., McKay, C.P. \& Navarro-González, R. (2008). Atacama Desert soil microbiology. In Microbiology of Extreme Soils, ed. Dion, P., Nautiyal, C.S. \& Varma, A., volume 13, pp. 117-132. Springer, Berlin, Heidelberg.

Grant, J., Westall, F., Beaty, D., Cady, S., Carr, M., Ciarletti, V., Coradini, A., Elfving, A., Glavin, D., Goesmann, F. et al. (2010). Two rovers to the same site on Mars, 2018: possibilities for cooperative science. Astrobiology 10, 663-685.

Hammer, Ø., Harper, D.A.T. \& Ryan, P.D. (2001). PAST: Paleontological statistics software package for education and data analysis. Palaeontol. Electron. 4(1), 9. http://palaeo-electronica.org/2001_1/past/issue1_01.htm

He, Z., Wu, L., Li, X., Fields, M.W. \& Zhou, J. (2005). Empirical establishment of oligonucleotide probe design criteria. Appl. Environ. Microbiol. 71, 3753-3760.

Hecht, M.H., Kounaves, S.P., Quinn, R.C., West, S.J., Young, S., Ming, S.W., Catling, D.C., Clark, B.C., Boynton, W.V., Hoffman, J. et al. (2009). Detection of perchlorate and the soluble chemistry of the Martian soil at the Phoenix lander site. Science 325, 64-67.

Henneberger, R.M., Walter, M.R. \& Anitori, R.P. (2006). Extraction of DNA from acidic, hydrothermally modified volcanic soils. Environ. Chem. 3, 100-104.

Herrera, A. \& Cockell, C.S. (2007). Exploring microbial diversity in volcanic environments: a review of methods in DNA extraction. J. Microbiol. Methods 70, 1-12.

Hintze, L.H. \& Kowallis, B.J. (2009). The Geologic History of Utah. Brigham Young University Geology Studies Special Publication 9, Provo, Utah.

Khanna, M. \& Stotzky, G. (1992). Transformation of bacillus subtilis by DNA bound on montmorillonite and effect of DNAse on the transforming ability of bound DNA. Appl. Environ. Microbiol. 58, 1930-1939.

Klingelhofer, K., Morris, R.V., Bernhardt, B., Schröder, C., Rodionov, D.S., de Souza, P.A., Yen, A., Gellert, R., Evlanov, E.N., Zubkov, B. et al. (2004). Jarosite and hematite at Merdiani lanum from opportunity's Mossbauer spectrometer. Science 306, 1740.

Knoll, A.H. \& Grotzinger, J. (2006). Water on Mars and the prospect of Martian life. Elements 2, 171-175.

Kotler, J.M., Hinman, N.W., Richardson, C.D., Conly, A.G. \& Scott, J.R. (2009). Laboratory simulations of prebiotic molecule stability in the jarosite mineral group; end member evaluation of detection and decomposition behavior related to Mars sample return. Planet. Space Sci. 57(12), 1381-1388.

Kotler, J.M., Hinman, N.W., Scott, J.R., Yan, B. \& Stoner, D.L. (2008). Glycine identification in natural jarosites using laser-desorption Fourier transform mass spectrometry: implications for the search for life on Mars. Astrobiology 8(2), 253-266.

Kotler, M., Quinn, R., Foing, B.H., Martins, Z. \& Ehrenfreund, P. (2011). Analysis of mineral matrices of planetary soils analogs from the Utah desert. Int. J. Astrobiol. 10, 221-229.

Liang, M.C., Hartman, H., Kopp, R., Kirschvink, J. \& Yung, Y. (2006). Production of hydrogen peroxide in the atmosphere of a snowball earth and the origin of oxygenic photosynthesis. Proc. Nat. Acad. Sci. U.S.A. 103 (50): 18896-18899.

Lester, E.D., Satomi, M. \& Ponce, A. (2007). Microflora of extreme arid Atacama Desert soils. Soil Biol. Biochem. 39, 704-708.

Malin, M.C. \& Edgett, K.S. (2003). Evidence for persistent flow and aqueous sedimentation on early Mars. Science 302, 1931-1934.

Marlow, J., Martins, Z. \& Sephton, M. (2010). Organic host analogues and the search for life on Mars. Int. J. Astrobiol. 10, 31-44.

Martins, Z., Hofmann, B., Gnos, R., Greenwood, R., Verchovsky, A., Franchi, I., Jull, A., Botta, O., Glavin, D., Dworkin, J. et al. (2007). Amino acid composition, petrology, geochemistry, ${ }^{14} \mathrm{C}$ terrestrial age and oxygen isotopes of the Shisr $033 \mathrm{CR}$ chondrite. Meteorit. Planet. Sci. 42, 1581-1595.

Martins, Z., Sephton, M.A., Foing, B.H. \& Ehrenfreund, P. (2011). Extraction of amino acids from soils close to the Mars desert research station (MDRS), Utah. Int. J. Astrobiol. 10, 231-238.

Milliken, R.E., Bristow, T. \& Bish, D.L. (2011). Diagenesis of clay minerals on Mars and implications for the Mars Science Laboratory Rover. In 42nd Lunar and Planetary Science Conference, Woodlands, Abstract no. 2230. Ming, D.W., Lauer, H.V., Archer, P.D., Sutter, B., Golden, D.C., Morris, R. V., Niles, P.B. \& Boynton, W.V. (2009). Combustion of organic molecules by the thermal decomposition of perchlorate salts: Implications for organics at the Mars Phoenix Scout Landing Site. In 40th Lunar and Planetary Science Conference, Woodlands, Abstract no. 2241.

Moore, D.M. \& Reynolds, R.C. (1997). X-Ray Diffraction and the Identification and Analysis of Clay Minerals. 378 pp. Oxford University Press, NewYork.

Mumma, M.J., Villanueva, G.L., Novak, R.E., Hewagama, T., Bonev, B.P., DiSanti, M.A., Mandell, A.M. \& Smith, M.D. et al. (2009). Strong release of methane on Mars in northern summer 2003. Science 323, 1041-1045.

Murchie, S.L., Mustard, J.F., Ehlmann, B.L., Milliken, R.E., Bishop, J.L., McKeown, N.K., Noe Dobrea, E.Z., Seelos, F.P., Buczkowski, D.L., Wiseman, S.M. et al. (2009). A synthesis of Martian aqueous mineralogy after 1 Mars year of observations from the Mars Reconnaissance Orbiter. J. Geophys. Res. 114, E00D06. 
Nadeau, P.H. \& Reynolds, C.R. (1981). Burial and contact metamorphism in the Mancos Shale. Clays Clay Miner. 29, 249-259.

Navarro-González, R., Rainey, F.A., Molina, P., Bagaley, D.R., Hollen, B.J., de la Rosa, J., Small, A.M., Quinn, R.C., Grunthaner, F.J., Cáceres, L. et al. (2003). Mars-like soils in the Atacama Desert, Chile, and the dry limit of microbial life. Science 302, 1018-1021.

Navarro-González, R., Vargas, E., de la Rosa, J., Raga, A.C. \& McKay, C.P. (2010). Reanalysis of the Viking results suggests perchlorate and organics at midlatitudes on Mars. J. Geophys. Res. 115(12), E12010.

Ormö, J., Komatsu, G., Chan, M.A., Beitler, B. \& Parry, W.T. (2004). Geological features indicative of processes related to the hematite formation in Meridiani Planum and Aram Chaos, Mars: a comparison with diagenetic hematite deposits in southern Utah, USA. Icarus 171, 295-316.

Orzechowska, G.E., Kidd, R., Foing, B.H., Kanik, I., Stoker, C. \& Ehrenfreund, P. (2011). Analysis of Mars analog soil samples using solid phase microextraction, organic solvent extraction and gas chromatography/mass spectrometry. Int. J. Astrobiol. 10, 209-219.

Parnell, J., Cullen, D., Sims, M.R., Bowden, S., Cockell, C.S., Court, R., Ehrenfreund, P., Gaubert, F., Grant, W., Parro, V. et al. (2007). Searching for life on Mars: selection of molecular targets for ESA's Aurora Exomars Mission. Astrobiology 7/4, 578-604.

Patel, M.R., Zarnecki, J.C. \& Catling, D.C. (2002). Ultraviolet radiation on the surface of Mars and the Beagle 2 UV sensor. Planet. Space Sci. 50(9), 915-927.

Peeters, Z., Quinn, R., Martins, Z., Sephton, M.A., Becker, L., Brucato, J., Grunthaner, F. \& Ehrenfreund, P. (2009). Habitability on planetary surfaces: interdisciplinary preparation phase for future Mars missions. Int. J. Astrobiol. 8(4), 301-315.

Pietramellara, G., Ascher, J., Ceccherini, M., Nannipieri, P. \& Wenderoth, D. (2007). Adsorption of pure and dirty bacterial DNA on clay minerals and their transformation frequency. Biol. Fertil. Soils $\mathbf{4 3}(6)$, 731-739.

Ponnamperuma, C., Shimoyama, A. \& Friebele, E. (1982). Clay and the origin of life. Orig. Life 12(1), 9-40.

Poulet, F., Beaty, D.W., Bibring, J.-P., Bish, D., Bishop, J.L., Noe Dobrea, E., Mustard, J.F., Petit, S. \& Roach, L.H. (2009). Key scientific Questions and key investigations from the First International Conference on Martian Phyllosilicates. Astrobiology 9, 257-267.

Quinn, R., Zent, A., Grunthaner, F., Ehrenfreund, R., Taylor, C. \& Garry, J. (2005). Detection and characterization of oxidizing acids in the Atacama Desert using the Mars oxidation instrument. Planet. Space Sci. 53, 1376-1388.

Richardson, C.D., Hinman, N.W., McJunkin, T.R., Kotler, J.M. \& Scott, J. R. (2008). Exploring biosignatures associated with Thenardite by geomatrix-assisted laser desorption/ionization Fourier transform ion cyclotron resonance mass spectrometry (GALDI-FTICR-MS). Geomicrobiol. J. 25, 1-9.

Rutherford, P.M. \& Juma, N.G. (1992). Influence of texture on habitable pore space and bacterial-protozoan populations in soil. Biol. Fertil. Soils 12, 221-227.

Saeki, K. \& Sakai, M. (2009). The influence of soil organic matter on DNA adsorptions on andosols. Microbes Environ. 24(2), 175-179.

Sephton, M.A. (2002). Organic compounds in carbonaceous meteorites. Nat. Prod. Rep. 19, 292-311.

Sephton, M.A. (2010). Organic geochemistry and the exploration of Mars, J. Cosmol. 5, 1141-1149.
Soffen, G.A. (1977). The Viking project. J. Geophys. Res. 82(28), 3959-3970 Squyres, S., Grotzinger, J.P., Arvidson, R.E., Bell, J.F., Calvin, W., Christensen, P.R., Clark, B.C., Crisp, J.A., Farrand, W.H., Herkenhoff, K.E. et al. (2004). In-situ evidence for an ancient aquaeus environment at Meridaini Planum. Science 306, 1709.

Squyres, S.W., Knoll, A.H., Arvidson, R.E., Ashley, J.W., Bell III, J.F., Calvin, W.M., Christensen, P.R., Clark, B.C., Cohen, B.A., de Souza Jr., P.A. et al. (2009). Exploration of Victoria crater by the Mars rover opportunity. Science 324, 1058-1061.

Stoker, C., Zent, A., Catling, D.C., Douglas, S., Marshall, J.R., Archer, D., Clark, B., Kounaves, S.P., Lemmon, M.T., Quinn, R. et al. (2010). Habitability of the Phoenix landing site. J. Geophys. Res. 115, E00E20.

Stoker, C., Clarke, J., Direito, S., Martin, K., Zavaleta, J., Blake, D. \& Foing, B.H. (2011). Chemical, mineralogical, organic and microbial properties of subsurface soil cores from the Mars Desert Research Station Utah, a phyllosilicate and sulfate rich Mars analog site. Int. J. Astrobiol. 10, 269-289.

Tegelaar, E.W., Deleeuw, J.W., Derenne, S. \& Largeau, C. (1989). A reappraisal of kerogen formation, Geochem. Geophys. Acta 53, 3103-3106.

Ten Kate, I. (2010). Organics on Mars. Astrobiology 10(6), 589.

Tielens, A.G.G.M. (2008). Interstellar polycyclic aromatic hydrocarbon molecules. Annu. Rev. Astron. Astrophys. 46, 289-337.

Thiel, C., Ehrenfreund, P., Foing, B.F., Pletser, V. \& Ullrich, O. (2011a). PCR-based analysis of microbial communities during the EuroGeoMars campaign at Mars Desert Research Station, Utah. Int. J. Astrobiol. 10, 177-190.

Thiel, C., Pletser, V. \& Foing, B.F. (2011b). Human crew related aspects for Astrobiology research. Int. J. Astrobiol. 10, 255-267.

Tosca, N.J. \& Hurowitz, J.A. (2011). Neoformation, diagenesis and the clay cycle on early Mars. In 42nd Lunar and Planetary Science Conference, Woodlands, Abstract no. 2031

Tosca, N.J., Knoll, A.H. \& Mc Lennan, S.M. (2008). Water activity and the challenge for life on early Mars. Science 320, 1204-1207.

Tritz, J.P., Herrmann, D., Bisseret, P., Connan, J. \& Rohmer, M. (1999). Abiotic and biological hopanoids transformation: towards the formation of molecular fossils of the hopane series. Org. Geochem. 30, 499-514.

Westall, F. (2009). Life on an anaerobic planet. Science 232, 471-472.

Westall, F., Brack, A., Hofmann, B., Horneck, G., Kurat, G., Maxwell, J., Ori, G.G., Pillinger, C., Raulin, F., Thomas, N. et al. (2000). An ESA study for the search for life on Mars. Planet. Space Sci. 48 , 181-202.

Yan, B., Stoner, D.L., Kotler, J.M., Hinman, N.W. \& Scott, J.R. (2007). Detection of biosignatures by geomatrix-assisted laser desorption/ ionization (GALDI) mass spectrometry. Geomicrobiol. J. 24(3-4), 379-385.

Yen, A.S., Kim, S.S., Hecht, M.H., Frant, M.S. \& Murray, B. (2000). Evidence that the reactivity of the Martian soil is due to superoxide ions. Science 289, 1909-1912.

Zegers, T. et al. (2011). Summary outcome and recommendations: workshop on landing sites for exploration missions, Leiden/Noordwijk, January 2011 (http://www.planetarygis.org/wiki/Workshop2011/Results).

Zahnle, K., Freedman, R.S. \& Catling, D.C. (2011). Is there methane on Mars? Icarus 212, 493-503.

Zhou, J., Bruns, M.N. \& Tiedje, J.M. (1996). DNA recovery from soils of diverse composition. Appl. Environ. Microbiol. 62(2), 316-322. 